\title{
PENGGALIAN DAN INVENTARISASI 1000 JUDUL NASKAH MELAYU DI BANDA ACEH
}

\author{
Nurdin AR \\ dinaratjeh@gmail.com \\ Program Studi Bahasa dan Sastra Arab Fakultas Adab dan Humaniora \\ Universitas Islam Negeri (UIN) Ar-Raniry Banda Aceh
}

\begin{abstract}
The most Indonesian written manuscripts were written in the Netherlands language. These manuscripts could be accessed by one of the following catalogs: Juynboll Catalogue (1899), Ronkel Catalogues (1909), Riclefs and P. Voorhoeve Catalogue (1977) etc. Unfortunately, the Indonesian researchers have no way to utilize them. According to the international catalogs written in Indonesian and foreign languages, The Malay manuscripts found in Banda Aceh reached about 300 titles. After conducting preliminary research and direct observation to the individual and institutional collectors, it was found that the real numbers of them could reach to a thousand titles of manuscripts that still have separated in various local places. On behalf these facts, the research aims to rescue these manuscripts from a disappearing and extinction by conducting inventory that is predicted to be able to push the Indonesian researchers ahead to discovering their substantial contents that in opinion useful for human life. The output of the research is compiling catalog documents of 1000 titles of Malay manuscripts found in Banda Aceh. The theory and method used in this research are the theory of the codicology and the method of the catalog of manuscripts register. The codicology is subfield studying all of the manuscript's aspects in details such as the place of storing, the owner of the manuscript, the content of the manuscript, etc. Whereas the catalog of a manuscript register is describing all of systematically manuscript's physical and objective aspect in details. The results of the research will be proposed to be the main gate for entering later philology works i.e. presenting and interpreting the text that in turn can be positioned as a manual directive in social and national life.
\end{abstract}

Keywords: Inventory, codicology, textology, catalog.

$$
\begin{aligned}
& \text { ملخص }
\end{aligned}
$$

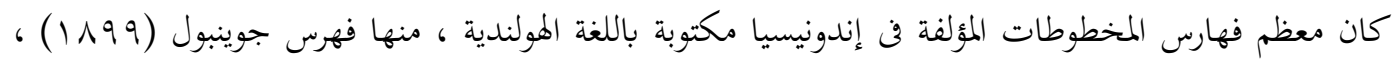

$$
\begin{aligned}
& \text { فهرس رونكل (9.9.9) فهرس ريكليفس و فورهوف (19VV) وغيرها متما جعل الباحثين الإندونيسين لا } \\
& \text { يستفيدون هها كثيرا ـ وقد ذكرت عدة فهارس المخطوطات العالمية المكتوبة باللغة الأجنبية والإندونيسية أن }
\end{aligned}
$$

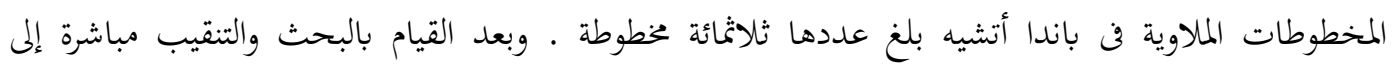

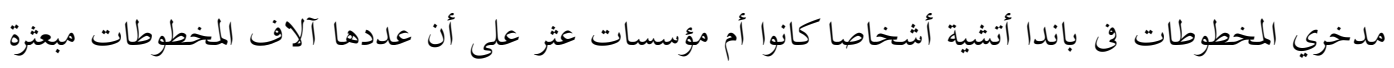

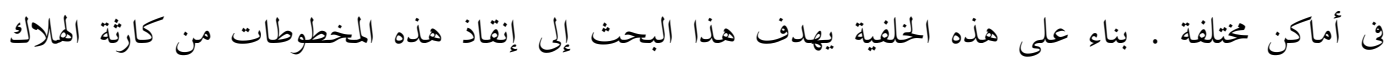

$$
\begin{aligned}
& \text { والانقراض عن طريقة الجمع والتصنيف حتى يستطيع الباحثون المحليون أن يكتشفوا ما تحتويه هذه المخطوطات }
\end{aligned}
$$

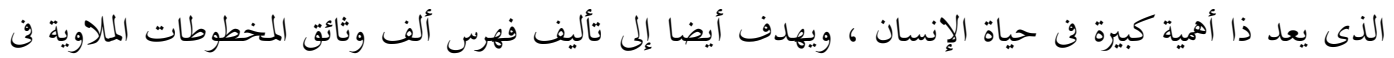

$$
\begin{aligned}
& \text { باندا أتشيه ـ. النظريات والمناهج المستخدمة في هذا البحث نظرية علم المخطوطات ومنهج فهرسة المخطوطات. }
\end{aligned}
$$




$$
\begin{aligned}
& \text { يدرس علم المخطوطات جميع أحوال المخطوطات مثل مكان الاقتناء، وصاحب المخطوطة ومتواها وغيرها ، ويراد } \\
& \text { بفهرسة المخطوطات وصف أحوال المخطوطات بالتفصيل والترتيب ظرفية كانت أم موضوعية . ويرجى أن تصبح } \\
& \text { نتائج هذا البحث سبيلا إلى عملية تحقيق التراث من خلال إعداد النص وشرحه الذى قام به الباحثون من أجل } \\
& \text { خلق المرجعيات الأساسية في الحياة الاجتماعية والوطنية . } \\
& \text { الكلمات المفتاحية: فهرس جوينبول ، فهرس رونكل ، فهرس ريكليفس و فورهوف . }
\end{aligned}
$$

\section{PENDAHULUAN}

Berabad-abad yang lalu, Aceh memiliki kenangan sejarah yang gemilang sehingga Aceh dikenal sebagai pusat ilmu pengetahuan dan kebudayaan. Pada zaman kerajaan Sultan Iskandar Muda (1606-1636 M.) terdapat para ulama yang berkepribadian tinggi dan berotak cerdas serta telah menghasilkan banyak karya yang dapat dibaca hingga sekarang. Mereka adalah Syaikh Hamzah Fansuri, Syaikh Syamsuddin As-Samatra'i, Syaikh Nuruddin Ar-Raniri, dan Syaikh Abdurrauf As-Singkili. Kehadiran para ulama produktif di daerah ini tidak pernah putus hingga awal abad ke-20 dan bahkan diteruskan oleh para ulama berikutnya, seperti Syaikh Burhanuddin, Syaikh Jalaluddin, Syaikh Muhammad Zain, dan lain sebagainya.

Mereka meninggalkan warisan intelektual yang berupa naskah-naskah dan berisi berbagai macam ilmu pengetahuan dan kebudayaan, terutama ilmu pengetahuan dan kebudayaan Islam. Naskah-naskah yang dimaksudkan adalah hasil sastra yang ditulis dengan tulisan tangan pada kertas dengan tulisan Jawi (Arab-Melayu) maupun tulisan Arab (berbahasa Arab). Naskah-naskah tersebut sekarang ini mulai mengalami proses menghilang dan punah karena dimakan oleh zaman, bencana tsunami (24 Desember 2004) ataupun oleh faktorfaktor lain. Menghadapi keadaan tersebut, maka perlu segera dilakukan penggalian dan inventarisasi melalui kerangka kerja filologis.

Setiap naskah merupakan sebuah saksi dari suatu dunia berbudaya atau suatu tradisi peradaban. Sudah barang tentu ada sejumlah naskah yang dipandang lebih menonjol daripada naskah-naskah lain karena peran penting dalam proses kesejarahan sastra yang bersangkutan. Setiap naskah menampilkan cerita dan menyimpan rahasianya yang kemudian baru terungkap setelah naskah itu dibuka, dibaca, dan diteliti. Proses pengungkapan ini dalam rangka membongkar sebuah teks dengan segala daya upaya yang dikenal sebagai kerja filologis. Salah satu kerja filologi yang dipandang paling awal adalah penggalian, pelacakan, dan inventarisasi naskahnaskah (Robson, 1994:ix). Karena itu, penggalian, pelacakan, dan inventarisasi 1000 judul naskah-naskah Melayu di Banda Aceh merupakan masalah pokok yang akan diteliti.

Penelitian tentang penggalian dan inventarisasi 1000 naskah-naskah Melayu di Banda Aceh ini bertujuan menyelamatkan, memelihara, dan mengembangkan warisan budaya bangsa yang tertuang di dalam naskah-naskah lama yang jumlahnya lebih dari 1000 judul. Kegiatan yang dilakukan adalah penggalian, penelitian, pemeliharaan, dan pengembangan, terutama bidang-bidang yang sedang mengalami proses menghilang atau musnah. Perlu diketahui bahwa beberapa naskah Melayu yang berada di Banda Aceh telah rapuh dan lapuk karena dimakan zaman maupun kutu buku.

Sasaran penelitian ini adalah penyusunan dukumentasi katalogus 1000 judul naskah-naskah Melayu yang berada di Banda Aceh. Dengan penyusunan 
katalogus daftar naskah ini diharapkan akan sangat berguna bagi para peneliti untuk melakukan kerja filologi selanjutnya. Kerja filologi tersebut dapat berupa penyuntingan teks, baik pentranskripsi-an, pen-transliterasi-an, penyajian dan interpretasi teks-teksnya sehingga kekayaan rohani yang berupa ilmu pengetahuan dan kebudayaan nenek moyang dapat dibaca dan dirasakan oleh generasi sekarang.

Teori dan metode mempunyai peran penting dalam memecahkan permasalahan yang dihadapi. Dengan menguasai teori dan metode, kesulitan atau permasalahan yang dihadapi dapat dipecahkan dengan mudah dan cepat karena teori merupakan tuntunan kerja, sedangkan metode merupakan cara kerjanya.

Berpijak pada latar belakang, masalah, dan uraian di atas, maka teori yang dimanfaatkan di dalam penelitian ini adalah kodikologi atau pernaskahan. Kodikologi merupakan suatu ilmu yang mempelajari seluk-beluk semua aspek naskah, antara lain tempat penyimpanan, tempat penulisan, pemilik naskah, bahan kertas yang digunakan untuk menulis, umur naskah, dan lain sebagainya (Baroroh-Baried dkk., 1994:56).

\section{PEMBAHASAN}

Agama Islam mulai tersebar di kepulauan Nusantara diperkirakan sejak abad ke-7 M. (Iskandar, 1996:100). Namun demikian, kerajaan Islam di kawasan ini baru muncul pada abad ke-13 M., yaitu dengan didirikannya Kerajaan Samudra Pasai oleh Sultan MalikushShalih yang wafat pada tahun 696 H./1297 M. (Daudy, 1983).

Menurut sejarawan Amerika Serikat, Allan Nevins (dalam Ibrahim Alfian, 1999:1) mengemukakan bahwa sejarah adalah jembatan yang menghubungkan masa lampau dengan masa kini dan menunjukkan jalan ke masa depan. Karena itu, Pasai yang terletak di Aceh Utara sekarang ini dan berada di garis pantai barat Selat Malaka adalah kerajaan pertama di Asia Tenggara yang memeluk agama Islam. Meskipun dikenal dengan nama Pasai dalam teks-teks Melayu, pelabuhan ini diberi nama "Samudra" oleh pedagang-pedagang India, yang pada akhirnya nama itu menjadi nama Pulau Sumatra. Antara tahun 1290 M. dan 1520 M., Kerajaan Pasai yang dalam Hikayat Raja-Raja Pasai disebut juga dengan nama Samudra Darussalam. Kerajaan tersebut tidak hanya memiliki kota dagang yang penting di Selat Malaka, tetapi juga menjadi pusat perkembangan Islam serta bahasa dan kesusastraan Melayu.

\section{Warisan Intelektual di Aceh}

Bahasa Melayu yang menjadi lingua franca telah diangkat di Aceh Utara menjadi Bahasa Kesusastraan dan diteruskan melalui pujangga-pujangga ahli sufi sehingga menjadi bahasa ilmu dan kebudayaan dan digunakan untuk menulis berbagai macam manuskrip yang berada di Aceh sehingga sampai saat ini manuskrip-manuskrip tersebut menjadi warisan intelektual bangsa Indonesia. Pada akhirnya, bahasa Melayu klasik yang datang dari Aceh Utara ini bertransformasi menjadi bahasa Indonesia dan tercantum dalam pasal 36 UndangUndang Dasar Republik Indonesia 1945 (Ibrahim Alfian, 1999:4).

Perang Aceh yang telah berlangsung hampir setengah abad dan telah menggegerkan dunia itu adalah suatu akibat dari dasar dan sistem pendidikan yang telah ditanamkan sejak Kerajaan Islam Peureulak (yang diproklamirkan pada hari Selasa 1 Muharram 225 H. atau 840 M.), Samudra Pasai (kira-kira tahun $696 \mathrm{H}$. atau 1297 M.) sampai kepada Kerajaan Aceh Darussalam (yang diproklamirkan pada tanggal, 12 Zulkaidah tahun $916 \mathrm{H}$. atau 1511 M.) dengan tegas menyatakan perang terhadap buta huruf dan buta ilmu pengetahuan (Hasymy, 1980:203).

Kesanggupan perang bagi rakyat Aceh bukanlah tumbuh secara mendadak, tetapi karena hasil tempaan sejak berabadabad yang lalu dan berlandaskan 
pendidikan Islam dan ilmu pengetahuan. Maka dari itu, Aceh pada saat tersebut merupakan sumber ilmu pengetahuan dengan sarjana-sarjananya yang terkenal, baik secara nasional maupun internasional sehingga banyak pemuda yang berduyunduyun datang ke Aceh (Hasymy, 1980:204).

Setelah Kerajaan Aceh Darussalam diproklamirkan pada tanggal 12 Zulkaidah tahun $916 \mathrm{H}$. atau $1511 \mathrm{M}$. sebagai hasil peleburan Kerajaan Islam Aceh di belahan Barat dan Kerajaan Islam Samudra Pasai di belahan Timur, maka putra Sultan Syamsu Syah diangkat menjadi raja dengan gelar Sultan Alauddin Ali Mughaiyat Syah. Dengan demikian, kota Banda Aceh disempurnakan namanya menjadi Banda Aceh Darussalam dan sebagai Ibukota Kerajaan Aceh Darussalam. Kota Banda Aceh Darussalam terus berkembang menjadi kota internasional dan bahkan menjadi pusat perkembangan ilmu pengetahuan dan kebudayaan (Hasymy, 1980:206).

Warisan ilmu pengetahuan dan kebudayaan Pasai, akhirnya diserap oleh Kesultanan Aceh yang baru bangkit pada tahun 1520-an. Warisan peradaban Islam Samudra Pasai yang kosmopolitan itu diteruskan oleh Kerajaan Aceh Darussalam. Perlu dikemukakan bahwa dalam catatan sejarah, masyarakat dan kebudayaan suku-suku bangsa di Nusantara telah banyak melahirkan pujangga-pujangga besar dengan karyakarya mereka yang bernilai tinggi. Daerah Aceh yang terletak di ujung paling barat wilayah Nusantara telah banyak melahirkan ulama-ulama dan pujanggapujangga terkenal sejak masa Kerajaan Samudra Pasai sampai awal abad ke-20, silih berganti dengan berbagai macam karya mereka dalam bentuk naskahnaskah yang berisi berbagai sumber ilmu pengetahuan dan kebudayaan, terutama pengetahuan keislaman dan kebudayaan Islam.

Dalam kejayaan Kesultanan Aceh Darussalam antara abad ke-16 dan ke-17, telah hadir ulama-ulama yang sangat produktif, seperti Syaikh Hamzah Fansuri, Syaikh Syamsuddin As-Samatra'i, Syaikh Nuruddin Ar-Raniri, dan Syaikh Aburrauf As-Singkili. Kehadiran para ulama produktif di daerah ini tidak pernah putus hingga awal abad ke-20 dan diteruskan oleh para ulama sesudahnya. Mereka antara lain seperti: Syaikh Burhanuddin (murid Abdurrauf), Syaikh Jalaluddin bin Muhammad Kamaluddin Tursani (yang hidup pada masa pemerintahan Sultan Alauddin Maharaja Lela Ahmad Syah tahun 1139-1147 H. atau 1727-1735 M.), Syaikh Jalaluddin (yang hidup pada masa pemerintahan Sultan Alauddin Johan Syah tahun 1147-1174 H. atau 1735-1760 M.), Syaikh Muhammad Zain (yang hidup pada masa pemerintahan Sultan Alauddin Mahmud Syah tahun 1147-1195 H. atau 1760-1781 M.), Syaikh Abdullah (yang hidup pada masa pemerintahan Sultan Alauddin Jauharul Alam Syah tahun 1209-1238 H. atau 1795-1823 M.), dan Syaikh Jamaluddin bin Syaikh Abdullah (yang hidup pada masa pemerintahan Sultan Alauddin Sulaiman Ali Iskandar Syah tahun 1251-1273 H. atau 1836-1857 M.) (Hasymy, 1980). Mereka banyak melahirkan karya-karya yang berupa naskah-naskah yang berserakan di berbagai tempat dan dapat ditemukan hingga sampai saat ini. Pada umumnya, karya-karya mereka mengandung nilai yang tinggi dan abadi. Karya-karya tersebut sampai saat ini masih tetap agung karena mengandung kekayaan rohani dan perbendaharaan pikiran nenek moyang yang luhur.

Yang dimaksud naskah di sini adalah hasil sastra yang ditulis dengan tulisan tangan pada kertas dengan tulisan Jawi (Arab-Melayu) maupun tulisan Arab (berbahasa Arab). Naskah-naskah tersebut sekarang banyak tersimpan di berbagai perpustakaan, museum, koleksi perseorangan maupun lembaga yang dipandang biasa menyimpan naskah.

Naskah-naskah tulisan tangan yang merupakan warisan intelektual nenek moyang tersebut berisi berbagai macam sumber ilmu pengetahuan dan 
kebudayaan, terutama pengetahuan keislaman dan kebudayaan Islam. Warisan intelektual yang dipandang tak ternilai dan merupakan harta karun yang tidak akan habis itu berupa naskah-naskah yang jumlahnya ribuan judul. Karena itu, naskah-naskah tersebut perlu segera ditangani untuk diselamatkan dari kepunahannya dan segera diinventarisir. Dari inventarisasi naskah-naskah Melayu yang ada di Banda Aceh ini akan membuka peluang yang sangat besar bagi para peneliti untuk mengungkapkan nilai yang terkandung di dalamnya karena karya-karya tersebut sangat berguna bagi kehidupan.

\section{Contoh Katalogus Melayu dari Hasil Penggalian dan Inventarisasi \\ 2.1 Sabila 'l-Muhtadi Li' 't-Tafaqquhi Fi Amri 'd-Din \\ Naskah ini adalah karya Syaikh} Muhammad Arsyad ibnu Abdillah alBanjari 1193 H (1779/80 AD) - 1195 H (1780/81 AD), M.S. Inv. 071/3456, salinan Abdurrauf Daya (Kabupaten Aceh Jaya sekarang) pada tahun $1264 \mathrm{H}$ (1847/48 AD), beraksara Arab dab Jawi, berbahasa Arab dan Melayu, ditulis dengan khath Naskhi memakai tinta tradisional berwarna hitam dan merah yang sangat rapi pada media kertas Eropa dengan cap air (watermark) bulan sabit bersusun tiga buatan Venesia $1726 \mathrm{M}$, ukuran naskah $22 \times 17 \mathrm{~cm}$, ukuran teks $14,5 \times 10 \mathrm{~cm}$, jumlah baris rata-rata perhalaman 21 baris kecuali pada halaman akhir (kolofon) 16 baris, penomoran halaman dengan kata alihan (catchword) berupa penulisan kata awal dari halaman kiri pada pojok kiri bawah halaman kanan pada setiap halaman kondisi fisik naskah sangat bagus dan utuh (kondisi prima). Penjilidan naskah secara tradisional berbentuk kuras (masing-masing 10 lembar kertas yang dilipat dua sehingga menjadi 20 halaman setiap kuras yang dijahit dan dirangkai dengan benang). Naskah dengan ketebalan 310 halaman ini berisi teks fiqh ubudiyah mazhab Syafi'i berdasarkan referensi utama kitab Shiratu
'l-Mustaqim karya Syeikh Nuruddin ArRaniri, yang menguraikan tentang bersuci dan air mutlak, najis besar dan kecil, wudhuk dan tayammum, mandi wajib dan mandi sunnat, qadha hajat, dan shalat wajib dan shalat sunnat. Teks ini sudah ada cetak batu (litografi) bersama teks Shiratu 'l-Mustaqim pada bagian pinggirnya.

\subsection{Safinatu 'l-Hukkam Fi Takhlishi 'l- Khasham}

Naskah ini adalah karya Syaikh Jalaluddin ibnu Syaikh Muhammad Kamaluddin ibnu al-Qadhi at-Tarusani, M.S. Inv. 073/1477, tidak disebutkan tahun penulisan dan nama penyalinnya, tetapi pada naskah lain dari koleksi A. Hasjmy (97/FK/3/YPAH/2005) disebutkan Jumat 4 Muharram $1153 \mathrm{H}$ (Jumat 1 April 1740 AD), asal-usul naskah dari Sayid Zainal Abidin warga Aceh Besar, beraksara Arab dan Jawi, berbahasa Arab dan Melayu, ditulis dengan khath Naskhi memakai tinta tradisional berwarna hitam dan merah yang sangat rapi pada media kertas eropa dengan tekstur licin tetapi cap air (watermark) tidak jelas, ukuran naskah 21 x $16 \mathrm{~cm}$, ukuran teks 14 x 12,5 cm, jamlah baris rata-rata perhalaman 20 baris kecuali pada halaman terakhir (kolofon) 11 baris, penomoran halaman dengan kata alihan (catchword) berupa penulisan kata awal dari halaman kiri pada pojok kiri bawah halaman kanan pada setiap halaman, kondisi fisik naskah yang masih sangat bagus dan utuh, kecuali halaman pertama agak rusak. Penjilidan naskah secara tradisional berbentuk kuras (masingmasing 10 lembar kertas yang dilipat dua sehingga menjadi 20 halaman setiap kuras yang dijahit dan dirangkai dengan benang). Naskah dengan ketebalan 652 halaman ini berisi teks figh muamalah yang menguraikan muqaddimah pertama tentang kata-kata wajib, sunnat, haram, harus, makruh, sunnat shahih, batal, syarat dan masyrut lazim, maklum, hukum, adat, qanun, dan resam; muqaddimah kedua mengenai tugas-tugas, kewajiban, dan 
syarat-syarat menjadi sultan, wazir, qadhi, hulubalang, dan lain-lain; bab pertama tentang hukum dagang, pasal-pasal tentang kaidah dan petunjuk-petunjuk bagi hakim dan qadhi; bab kedua tentang nikah dan perkawinan, serta pasal-pasal tentang petunjuk dan kaidah-kaidah yang berkaitan dengan nikah; dan bab ketiga tentang hukum pidana dan pasal-pasal mengenai kaidah dan petunjuk-petunjuk bagi hakim berkaitan dengan hukum pidana. Teks ini ditulis atas permintaan Sultan Alauddin Johan Syah, Sultan Aceh Darussalam ke-24 yang berkuasa antara $1735-1760 \mathrm{M}$.

\subsection{Hidayatu 's-Salikin Ila 'Ibadati Rabbi 'l-'Alamin (Jilid 1)}

Naskah ini adalah Naskah ini adalah karya Syakh Abdussamad al-Jawi al-Falimbani, Mekkah 5 Muharram 1192 H (Tuesday 3 February 1778 AD), M.S. Inv. 072/1476, nama penyalin tidak disebutkan, naskah berasl dari M. Yusuf (Aceh Besar), beraksara Arab dan Jawi, berbahasa Arab dan Melayu, ditulis dengan khath Naskhi memakai tinta tradisional berwarna hitam dan merah yang sangat rapi pada media kertas Eropa dengan cap air (watermark) Liberta, VG buatan tahun $1820 \mathrm{M}$, ukuran naskah $22 \mathrm{x}$ $15 \times 9 \mathrm{~cm}$, ukuran teks $15 \times 10 \mathrm{~cm}$, jumlah baris perhalaman rata-rata 17 baris, kecuali pada halaman terakhir (kolofon) 8 baris, pada halaman akhir (kolofon) terdapat hiasan pigura indah (illuminasi), penomoran halaman dengan kata alihan (catchword) berupa penulisan kata awal dari halaman kiri pada pojok kiri bawah halaman kanan pada setiap halaman, kondisi fisik naskah bagus, lengkap, dan prima. Penjilidan naskah secara tradisional berbentuk kuras (masing-masing 10 lembar kertas yang dilipat dua sehingga menjadi 20 halaman setiap kuras yang dijahit dan dirangkai dengan benang). Naskah dengan ketebalan 338 halaman ini berisi teks tasawuf yang mengikuti ajaran tasawuf Imam Ghazali yang terbagi kepada beberapa bab dan pasal-pasalnya, misalnya tentang kelebihan ilmu yang bermanfaat dan kelebihan orang yang menuntut ilmu, dasar-dasar akidah Ahlussunnah wal Jamaah, ibadah lahir, menjauhi perbuatan maksiat, jenis-jenis perbuatan maksiat batin, ajaran dan zikir sufi, adab orang alim, adab orang belajar, adab anak kepada orang tua, dan adab bersahabat.

\subsection{Masa-ila 'l-Muhtadi Li Ikhwani' 'l- Mubtadi dan Bidayatu 'l-Mubtadi Li Ikhwani 'l-Muhdi}

Naskah ini adalah naskab berkode M.S. Inv. 077/1481, tidak disebutkan nama penulis dan penyalinnya, naskah berasal dari Teuku Bahrum (Aceh Besar), beraksara Arab dan Jawi, berbahasa Arab dan Melayu, ditulis dengan khath Naskhi memakai tinta tradisional berwarna hitam dan merah yang cukup rapi pada media kertas Eropa, tetapi cap air (watermark) tidak jelas, ukuran naskah $22 \times 15,5 \mathrm{~cm}$, ukuran teks $14 \times 10 \mathrm{~cm}$, jumlah baris perhalaman 17 baris, kecuali pada bagian awal teks (eksordium) 5 baris dan pada bagian akhir teks (kolofon) 12 baris, pada dua halaman awal terdapat hiasan pigura (illuminasi), penomoran halaman dengan kata alihan (catchword) berupa penulisan kata awal dari halaman kiri pada pojok kiri bawah halaman kanan pada setiap halaman, kondisi fisik naskah masih bagus tetapi penjilidan lapas-lepas. Penjilidan naskah secara tradisional berbentuk kuras (masing-masing 10 lembar kertas yang dilipat dua sehingga menjadi 20 halaman setiap kuras yang dijahit dan dirangkai dengan benang). Naskah dengan ketebalan 178 halaman ini berisi 2 teks, yaitu Masa-ilal-Muhtadi Li Ikhwanil-Mubtadi yang mengandung pokok-pokok ajaran agama Islam, tentang iman, tauhid, makrifat, syarat, rukun, wajib, haram, mubah, makruh, dan batal yang disajikan dalam bentuk tanya-jawab, dan teks Bidayatul-Mubtadi Li IkhwanilMuhdi yang mengandung tentang Islam, tauhid, makrifat, air yang dipergunakan untuk bersuci, qadha hajat, najis, bermasam-macam shalat wajib dan 
sunnat, puasa, dan shalat tarawih. Teks ini sudah banyak dicetak batu (litografi) dan masih dipakai sebagai bahan ajar pada pendidikan Islam tingkat pemula di sebagian daerah di Indonesia.

\subsection{Shirathu l-Mustaqim}

Naskah ini adalah karya Syaikh Nuruddin ibnu Ali ibnu Hasanji ibnu Muhammad Hamid ar-Raniri 1044 H (1634/35 AD), M.S. Inv. 0717/1491, nama penyalin tidak disebutkan, naskah berasal dari Sayid Muhammad (Peukan Bada Aceh Besar), beraksara Arab dan Jawi, berbahasa Arab dan Melayu, ditulis dengan khath Naskhi memakai tinta tradional berwarna hitam dan merahyang cukup rapi pada media kertas Eropa dengan cap air (watermark) bulan sabit tersenyum dalam perisai (Andrea Galvani Pordenone AG, tidak ada keterangan tempat (No Place/NP) dan tanpa tahun produksi (No Date/ND) : Heawood, 1950: 84/ lampiran 860, ukuran naskah 23,3 x $16,5 \mathrm{~cm}$, ukuran teks $16,7 \times 9,5 \mathrm{~cm}$, jumlah baris rata-rata perhalaman 19 baris kecuali pada halaman awal (eksordium) 9 baris, pada dua halaman awal terdapat hiasan pigura (illuminasi), penomoran halaman dengan kata alihan (catchword) berupa penulisan kata awal dari halaman kiri pada pojok kiri bawah halaman kanan pada setiap halaman, kondisi fisik naskah bagus. Penjilidan naskah secara tradisional berbentuk kuras (masingmasing 10 lembar kertas yang dilipat dua sehingga menjadi 20 halaman setiap kuras yang dijahit dan dirangkai dengan benang). Naskah dengan ketebalan 469 halaman ini berisi teks fiqh ubudiyah tentang shalat, puasa, zakat, haji, hokum kurban, berburu dan halal haramnya, dan makanan halal dan haramnya. Teks ini sudah ada cetak batu (litografi) dan masih dipakai untuk bahan ajar ilmu keislaman di sebagian daerah di Indonesia.

\subsection{Silsilah Thariqat Syaththariyyah}

Naskah ini adalah naskah berkode M.S. Inv. 0723/1497, tidak disebutkan nama penulisnya, tetapi pada naskahnaskah lain disebutkan teks ini ditulis oleh
Syaikh Abdurrauf al-Jawi al-Fashuri asSinkili (w. 1104/05 H (1693 M ), khalifah utama tarikat tersebut di Nusantara, nama penyalin, tahun, dan tempat penyalinan tidak disebutkan, naskah berasal dari Teuku Bahrum (Aceh Besar), beraksara Arab dan Jawi, berbahasa Arab dan Melayu, ditulis dengan khath Naskhi memakai tinta tradional berwarna hitam dan merah yang cukup rapi pada media kertas Eropa dengan cap air (watermark) tidak jelas, ukuran naskah $23 \times 17 \mathrm{~cm}$, ukuran teks $15 \times 9 \mathrm{~cm}$, jumlah baris untuk teks berbahasa Melayu rata-rata perhalaman 17 baris, kecuali pada bagian akhir (kolofon) 6 baris dan untuk teks berbahasa Arab rata-rata perhalaman 6 - 9 baris, kecuali pada bagian awal teks (eksordium) 5 baris, pada bagian awal terdapat hiasan pigira (illuminasi), teks berbahasa Arab diberi terjemahan antarbaris (interlinear) dalam bahasa Melayu, penomoran halaman dengan kata alihan (catchword) berupa penulisan kata awal dari halaman kiri pada pojok kiri bawah halaman kanan pada setiap halaman, kondisi fisik naskah bagus dan lengkap, tetapi pada bagian penjilidan rusak karena dimakan kutu buku (silverfish) sehingga penjilidannya lepaslepas. Penjilidan naskah secara tradisional berbentuk kuras (masing-masing 10 lembar kertas yang dilipat dua sehingga menjadi 20 halaman setiap kuras yang dijahit dan dirangkai dengan benang). Naskah dengan ketebalan 128 halaman ini berisi tentang silsilah tarekat Syaththariyah, kejadian Adam, malaikat, tauhid, syair, dan qashidah.

\subsection{I'tiqad, Ittihad wa 'l-Hulul, Qadhi Ma'zul tahun 1003 H (1594/95 AD)}

Naskah ini adalah naskah berkode M.S. Inv. 0792/1566, nama penyalin Muallim Krueng Raya pada hari Selasa waktu Dhuha 2 Rabiul Akhir, tahun tidak disebutkan, naskah berasal dari Banda Aceh, nama pemilik terakhir tidak tercatat, beraksara Arab dan Jawi, berbahasa Arab dan Melayu, ditulis dengan khath Naskhi memakai tinta 
tradional berwarna hitam dan merah yang cukup rapi pada media kertas Eropa bertesktur agar kasar dan tebal dengan cap air (watermark) bulan sabit bersusun tiga (Map of Levant "appresso D. Bertelli al segno del S. Marco in Margenia", Vinesia, tanpa tahun (ND/No Date): Heawood, 1950: 84/ lampiran 865, mungkin sekitar $1600 \mathrm{M}$, ukuran naskah $20 \times 15,5 \mathrm{~cm}$, ukuran teks $16,5 \times 10,3 \mathrm{~cm}$, jumlah baris rata-rata perhalaman 23 baris, kecuali pada bagian akhir teks (kolofon) 19 baris, penomoran halaman dengan kata alihan (catchword) berupa penulisan kata awal dari halaman kiri pada pojok kiri bawah halaman kanan pada setiap halaman, kondisi fisik naskah bagus dan lengkap, tetapi pada bagian bawah penjilidan naskahnya sudah hilang rontok karena lembab dan halaman terakhir berlubang-lubang dimakan kutu buku (silverfish). Penjilidan naskah secara tradisional berbentuk kuras (masingmasing 10 lembar kertas yang dilipat dua sehingga menjadi 20 halaman setiap kuras yang dijahit dan dirangkai dengan benang). Naskah dengan ketebalan 20 halaman ini berisi pembahasan tasawuf tentang i'tiqad, ittihad, dan hulul, pengertian ma'u 'l-hayah sesuai dengan syair Syeikh Hamzah Fanshuri, mengucap shalawat, pengertian Qul huwa 'l-Lah, cara beribadah guna mendapatkan ilmu laduni (ilmu mengenal nama dan sifat Allah yang Dianugerahkan-Nya langsung ke dalam hati hamba-hamba yang salih), dan lain-lain. Pada bagian awal teks (eksordium) penulis yang menyebut dirinya sebagai Qadhi Ma'zul Hafizhahu 'l-Lah Ta'ala, menjelaskan bahwa ia menulis teks ini ketika ia diasingkan ke Syaharun Nur sebab ia difitnah orang pada 20 Ramadhan 1003 H (Monday 29 May 1595 AD).

\subsection{Khalqu 's-Samawati wal-Ardh}

Naskah ini adalah karya Syaikh Nuruddin ibnu Ali ibnu Hasanji ibnu Muhammad Hamid ar-Raniry, tahun 1047 H (1637/38 AD), M.S. Inv. 0793/1567, pada bagian awal teks (eksordium) penulisannya menyebutkan bahwa tatkala ia sampai ke Bandar Aceh hari Ahad 6 Rajab $1047 \mathrm{H}$ dan kemudian pada 20 Syawal $1047 \mathrm{H}$ ia diperintahkan oleh Sultan Iskandar Tsani Alauddin Mughayat Syah Johan Berdaulat zhilul-Lah fil-alam untuk menulis teks tetang kejadian langit dan bumi ini, nama penyalin, tempat, dan waktu penyalinan tidak disebutkan, nama pemilik terakhir tidak tercatat, beraksara Arab dan Jawi, berbahasa Arab dan Melayu, ditulis dengan khath Naskhi memakai tinta tradional berwarna hitam dan merah yang cukup rapi pada media kertas Eropa dengan cap air (watermark) Propatria buatan Belanda 1769 (Heawood, 1950:134/ lampiran 3151), ukuran naskah $20,5 \times 16,5 \mathrm{~cm}$, ukuran teks $16,5 \times 11,5$ $\mathrm{cm}$, jumlah baris rata-rata perhalaman 21 baris, kecuali pada bagian awal (eksordium) 6 baris dan akhir teks (kolofon) 16 baris, pada beberapa halaman terdapat penjelasan tambahan (scholia) pada pias halaman, penomoran halaman dengan kata alihan (catchword) berupa penulisan kata awal dari halaman kiri pada pojok kiri bawah halaman kanan pada setiap halaman, kondisi fisik naskah masih sangat bagus, lengkap, dan prima. Penjilidan naskah secara tradisional berbentuk kuras (masing-masing 10 lembar kertas yang dilipat dua sehingga menjadi 20 halaman setiap kuras yang dijahit dan dirangkai dengan benang). Naskah dengan ketebalan 80 halaman ini berisi tentang kejadian langit dan bumi, Luh Mahfuzh, Qalam, 'Arasy, Kursi, Nur Muhammad, Adam, malaikat, Sidratul Muntaha, jin, neraka, surga, bulan, bintang, dan lain-lain. Teks ini juga menyebutkan bahwa jika terjadi gempa besar, akan keluar air bah dari laut dan darat yang berwarna hitam dan kuning (Tsunami). Teks ini sudah ada cetak batu (litografi) pada pinggir kitab Tajul Muluk oleh Percetakan Al-Haramain Singapura, Jeddah, dan Indonesia.

\subsection{Bidayatul-Hidayah}

Naskah ini adalah karya Syaikh Muhammad Zain ibnu Tuan Faqih 
Jalaluddin al-Asyi tahun $1170 \mathrm{H}(1756 / 57$ AD), M.S. Inv. 0751/1525, nama penyalin, tempat, dan waktu penyalinannya tidak disebutkan, naskah berasal dari M. Yusuf (Aceh Besar), beraksara Arab dan Jawi, berbahasa Arab dan Melayu, ditulis dengan khath Naskhi memakai tinta tradional berwarna hitam dan merah yang cukup rapi pada media kertas Eropa, tetapi cap air (watermark) tidak jelas, ukuran naskah $24 \times 16 \mathrm{~cm}$, ukuran teks $16 \times 10 \mathrm{~cm}$, jumlah baris ratarata perhalaman 21 baris, kecuali pada bagian awal (eksordium) 14 baris dan akhir teks (kolofon) 23 baris, penomoran halaman dengan kata alihan (catchword) berupa penulisan kata awal dari halaman kiri pada pojok kiri bawah halaman kanan pada setiap halaman, kondisi fisik naskah masih sangat bagus, lengkap, dan prima. Penjilidan naskah secara tradisional berbentuk kuras (masing-masing 10 lembar kertas yang dilipat dua sehingga menjadi 20 halaman setiap kuras yang dijahit dan dirangkai dengan benang). Naskah dengan ketebalan 118 halaman ini berisi komentar terhadap Kitab Ummu ' $l$ Barahin karya Abu Abdillah Muhammad ibnu Yusuf al-Hasani as-Sanusi, imam, faqih mazhab Maliki, dan salah seorang mujtahid yang tinggal di Tilmisan/Tlemcen Tunisia dan meninggal 895 H (1489/90 AD). Teks Bidayatu 'lHidayah ini mengandung pembahasan tentang hukum syar' $i$, hukum 'adi, dan hukum 'aqli, tauhid dan sifat 20, sifatsifat Nabi, pengertian syahadat, dan tentang kalimah la ilaha illallah dan husnul khatimah, dan tentang pembagian ilmu; fiqh, usuluddin, dan tasawuf yang berasal dari Al-Quran dan hadits yang wajib dituntut oleh setiap muslim dewasa dan bertanggung-jawab (mukallaf). Dalam suatu pembahasan khusus (fa-idah) penulis menyebutkan tentang fitnah yang besar yang membinasakan agama Islam dengan kekerasan di sebagian negerinegeri di bawah angin (Nusantara) oleh bangsa Belanda yang dibantu oleh orangorang muslim yang aniaya (bughat) dan orang-orang yang murtad masuk agama
Nasrani. Sebagian orang Islam juga menjual muslim yang lain kepada kafir, orang-orang jahil mengaku dirinya alim, para pendatang (orang dagang) dan pribumi (orang negeri) bekerjasama membinasakan agama Islam dengan menghalalkan yang haram dan mengharamkan yang halal, sebagian orang mengkafirkan penghulu kita orangorang sufi dan ahli tarekat, mereka membolehkan bersuci dengan kitab suci mereka, mereka mencegah orang menyebut Allah hingga tidak ada lagi yang menyebut nama Allah pada negeri yang dahulu sudah makmur ini, dan sebagian lagi mengkafirkan orang yang menafikan ilahul bathil dengan la ilaha sebagaimana yang lainnya mengkafirkan orang yang menafikan sekalian alam dengan la ilaha, dan berbagai macam kemungkinan lainnya. Ini alamat kiamat (kehancuran). Syeikh Muhammad Zain ibnu Tuan Faqih Jalaluddin al-Asyiy merupakan Qadhi Malikul Adil/Syaikhul Islam Kesultanan Aceh Darussalam pada masa Sultan Alauddin Mahmud Syah I (1170-1195 H/1760-1781 M) (Hasjmy, 1975: 20), dan menyelesaikan karyanya ini di Mekkah 6 Muharram $1170 \mathrm{H}$ (Friday 1 October 1756 AD).

\subsection{Tarjumanul-Mustafid}

Naskah ini adalah karya Syaikh Abdurrauf ibnu Ali al-Jawi al-Fanshuri as-Sinkili, M.S.Inv. 0715/1609, nama penyalin, tempat dan waktu penyalinan tidak disebutkan, asal-usul naskah Banda Aceh tetapi nama pemilik terkhirnya tidak tercata, beraksara Arab dan Jawi, berbahasa Arab dan Melayu, ditulis dengan khath Naskhi memakai tinta tradional berwarna hitam dan merah yang cukup rapi pada media kertas Eropa dengan cap air (watermark) Propatria Propatria buatan Belanda 1769 (Heawood, 1950:134/ lampiran 3151), ukuran naskah $20 \times 16 \mathrm{~cm}$, ukuran teks $16 \times 11 \mathrm{~cm}$, jumlah baris rata-rata perhalaman 15 baris, penomoran halaman dengan kata alihan (catchword) berupa penulisan kata awal dari halaman kiri pada pojok kiri 
bawah halaman kanan pada setiap halaman, kondisi fisik naskah masih bagus, tetapi penjilidannya sudah lepaslepas. Penjilidan naskah secara tradisional berbentuk kuras (masingmasing 10 lembar kertas yang dilipat dua sehingga menjadi 20 halaman setiap kuras yang dijahit dan dirangkai dengan benang). Naskah dengan ketebalan 600 halaman ini berisi tesk Tafsir Al-Quran pertama dalam bahasa Melayu yang ditulis Syeikh Abdurrauf al-Jawi alFanshuri as-Sinkili (w.1693) dengan berpedoman pada Anwaru 't-Tanzil wa Asraru 't-Ta'wil karya Nashiruddin Abi Sa'id Abdullah ibnu Umar ibnu Muhammad asy-Syirazi al-Baidhawi. Teks ini sudah dicetak batu (litografi) oleh percetakan Darul Fikr Mesir 1410 H $(1989 / 90$ AD) di bawah redaksi Muhammad Idris Abdurrauf al-Marbawi al-Azhari.

\subsection{Hikayat Belanta Sena}

Naskah ini adalah naskah
anonimus,
07145/1619, nama penyalin dan tempat penyalinan tidak disebutkan, tahun penyalinan $1273 \mathrm{H}(1856 / 57 \mathrm{AD})$, asalusul naskah dari Banda Aceh, tetapi tidak disebutka nama pemilik terakhirnya, beraksara Jawi bahasa Melayu, ditulis dengan khath Naskhi memakai tinta tradional berwarna hitam dan merah yang cukup rapi pada media kertas Eropa dengan cap air (watermark) Chain Line 5, ukuran teks 32 x $22,5 \mathrm{~cm}$, ukuran teks 26 $\mathrm{x} 15 \mathrm{~cm}$, jumlah baris rata-rata perhalaman 29 baris, penomoran halaman dengan kata alihan (catchword) berupa penulisan kata awal dari halaman kiri pada pojok kiri bawah halaman kanan pada setiap halaman, kondisi fisik naskah masih bagus, tetapi sudah mulai rusak karena lapuk dan pejilidannya lepas-lepas. Penjilidan naskah secara tradisional berbentuk kuras (masing-masing 10 lembar kertas yang dilipat dua sehingga menjadi 20 halaman setiap kuras yang dijahit dan dirangkai dengan benang). Naskah ini dengan ketebalan 142 halaman ini berisi Hikayat Belanta Sena dalam bahasa Melayu (prosa), berlainan dengan hikayat yang umum dikenal dalam kesusastraan Aceh, yaitu cerita bersanjak (puisi). Teks ini mengandung cerita tentang kesaktian Raja Belanta Sena dari Negeri Balia Puri dalam menawan dan menawarkan sihir dan kesaktian musuhmusuhnya. Cerita ini terdiri atas beberapa babak. Kesimpulan cerita yang benar pada akhirnya selalu menang. Dalam cerita pertama misalnya, Karma Wande menyuruh ahli nujumnya supaya memanah Belanta Sena dengan panah sakti, tetapi tidak kena karena ia dipindahkan ke laut Bahrun Rajab, di mana Belanta Sena ditelan oleh Naga Kuntala. Ketika Belanta Sena sadar bahwa ia berada dalam perut naga, maka ia menepuk-nepuk pahanya sehingga keluarlah pedang saktinya dan ia pun membinasakan Naga Kuntala, dan seterusnya.

\subsection{Kumpulan Teks}

Naskah ini adalah naskah karyakarya(1) anonimus, (2) Syaikh Muhammad Zain ibnu Tuan Faqih Jalaluddin al-Asyi, dan (3) Syaikh Hamzah al-Fanshuri, M.S. Inv. 07106/1580, nama penyalin, tempat, dan waktu penyalinan tidak disebutkan, naskah beraksara Arab dan Jawi, berbahasa Arab dan Melayu, ditulis dengan khath Naskhi memakai tinta tradional berwarna hitam dan merah yang cukup rapi pada media kertas Eropa, tetapi cap air (watermark) Propatria Propatria buatan Belanda 1769 (Heawood, 1950:134/ lampiran 3151), ukuran naskah $20,5 \times 16 \mathrm{~cm}$, ukuran teks $14,5 \times 9,5 \mathrm{~cm}$, jumlah baris rata-rata perhalaman 19 baris, kecuali pada akhir teks (kolofon) 10 baris, penomoran halaman dengan kata alihan (catchword) berupa penulisan kata awal dari halaman kiri pada pojok kiri bawah halaman kanan pada setiap halaman, kondisi fisik naskah masih sangat bagus, lengkap, tetapi agak lembab dan berjamur. Penjilidan naskah secara tradisional berbentuk kuras (masing- 
masing 10 lembar kertas yang dilipat dua sehingga menjadi 20 halaman setiap kuras yang dijahit dan dirangkai dengan benang). Dalam naskah dengan ketebalan 69 halaman ini terdapat beberapa teks, yaitu (1) Qawa'idul Islam, tidak disebutkan nama penulis, tempat dan waktu penulisannya. Teks ini merupakan teks ilmu tauhid yang membahas tentang hukum akal dan sifat-sifat wajib pada Allah (sifat 20). (2) Kasyfu 'l-Kiran Fi Bayani 'n-Niyati 'Inda Takbirati 'lIhram, karya Syekh Muhammad Zain ibnu Tuan Faqih Jalaluddin al-Asyi, ditulis di Mekkah 8 Muharram $1171 \mathrm{H}$ (Thursday 22 September 1757 AD). Teks ini menjelaskan bahwa niat dalam takbiratul ihram terutama pada shalat wajib haruslah diisyaratkan qashad, ta'aradh, dan ta'ayyun dalam kalimat $a-l$ $l-a-h-u a-k-b-a-r$. Niat dalam takbiratul ihram itu haruslah muqaranah, yaitu muqaranah kamaliyah yang menghadirkan sekalian rukan 13 satu persatu, muqaranah basithah yang bersuku-suku, dan muqaranah 'arfiyah dengan menghadirkan yang diniatkan sebelum takbir. (3) Zinatul-Muwachchidin, karya Syaikh Hamzah al-Fanshuri, tempat dan waktu penulisan tidak disebutkan, tetapi pada bagian akhir teks (kolofon) nama pemilik dan penyalin disebutkan Leube Banda Krueng Mak mengaji pada Tuan Haji Po Sandang, tamat kitab waktu Dhuha 10 Ramadhan (tanpa tahun), lagi yang empunya kitab ini Teuku Raja. Isi teks ini sama persis dengan isi teks Syarabu 'l- 'Asyiqin karya penulis yang sama yang membahas tentang amalan syari'at, amalan tarekat, amalan hakekat, makrifat Allah Taala, tajalli zat Allah Taala, sifat Allah Taala, serta asyik dan syukur kepada Allah Taala.

Itulah sejumlah contoh katalogus naskah Melayu yang perlu segera dilakukan penggalian dan inventarisasi dan masih banyak naskah yang belum terjamah oleh para peneliti, baik peneliti yang berasal dari dalam negeri maupun para peneliti dari luar negeri. Melihat kenyataan di atas, tentu saja untuk menangani sejumlah naskah yang masih berserakan dan belum terjamah ini, diperlukan kerjasama dari sejumlah instansi agar kekayaan dan warisan budaya Indonesia bisa terselamatan dari kepunahan.

\section{KESIMPULAN}

Untuk mendeskripsikan selukbeluk semua aspek suatu naskah diperlukan suatu metode dan rujukan yang dipandang dapat dijadikan pegangan oleh para peneliti dalam mendeskripsikan suatu naskah yang diteliti. Karena itu, metode dan rujukan yang dimanfaatkan di dalam penelitian ini adalah metode daftar naskah dan katalogus daftar naskah.

Daftar naskah biasanya hanya memuat nomor urut dan judul naskah, sedangkan katalogus daftar naskah jauh lebih terurai dari suatu daftar naskah. Katalogus daftar naskah antara lain memuat panjang dan lebar halaman naskah dalam sentimeter, jumlah halaman, jumlah baris rata-rata pada satu halaman, huruf yang dipakai dalam naskah, tempat dan tanggal naskah ditulis kalau ada, asal naskah kalau ada, isi teks secara singkat, yang pernah membicarakan naskah itu, dan naskah-naskah lain dalam judul yang sama yang terdapat di berbagai kota, lembaga, maupun tempat-tempat lain.

Berdasarkan beberapa katalogus daftar naskah, baik katalogus Juynboll (1899), Ronkel (1909), Sutaarga, Amir dkk. (1972), catatan tambahan yang diambil dari "Manuscript Description" yang diajukan oleh Russel Jone tahun 1974 (dalam Rujiati-Mulyadi, 1994), katalogus Ricklefs dan P. Voorhoeve (1977), bahan tambahan dalam "Workshop on Malay Manuscripts tahun 1980 (dalam Rujiati-Mulyadi, 1994), kalalogus Voorhoeve et al. (1994), dan katalogus Behrend (1998) dapat disimpulkan bahwa memang tidak ada keseragaman dalam cara mendeskripsikan sebuah naskah. Karena itu, di dalam penelitian ini metode pendeskripsian yang dimanfaatkan adalah model 
pendeskripsian yang dibuat oleh RujiatiMulyadi (1994) dengan pengurangan dan penambahan yang disesuaikan dengan kondisi naskah yang dihadapi di lapangan.

Model pendeskripsian suatu naskah yang dimaksudkan meliputi pendeskripsian tentang: judul naskah, tempat penyimpanan naskah, nomor naskah, ukuran halaman, jumlah halaman, jumlah baris, panjang baris, jumlah kata, huruf yang dipakai, bahasa yang dipakai, kertas, cap kertas (watermark), garis tebal dan garis tipis, kuras, panduan, pengarang, penyalin, tempat penulisan naskah, keadaan naskah, pemilik naskah, pemerolehan naskah, gambar atau ilustrasi, isi (kandungan) naskah, dan catatan-catatan lain.

\section{DAFTAR PUSTAKA}

Baroroh-Baried, Siti dkk. 1994. Pengantar Teori Filologi. Badan Penelitian danPublikasi Fakultas (BPPF) Seksi Filologi Fakultas Sastra UGM, Yogyakarta.

Behrend, T.E. 1988. Katalog Induk Naskah-Naskah Nusantara Jilid 4 PerpustakaanNasional Republik Indonesia. Penerbit Kerjasama Yayasan Obor Indonesiadan Ecole Francaise d'Extreme-Orient (Perwakilan Jakarta) dengan The FordFoundation, Office for Indonesia (Jakarta) dan Perpustakaan Nasional Republik Indonesia, Jakarta.

Daudy, ahmad. 1983. Allah dan Manusia dalam Konsepsi Syaikh Nuruddin Ar-RaniryPenerbit Rajawali, Jakarta.

Hasymy, A. 1980. "Banda Aceh Darussalam Pusat Kegiatan Ilmu dan Kebudayaan"dalam Ismail Suny Bunga Rampai tentang Aceh. Penerbit Bhratara KaryaAksara, Jakarta.
Iskandar, Teuku. 1996. Kesusastraan Klasik Melayu Sepanjang Abad. Penerbit Libra,Jakarta.

Ibrahim Alfian, Teuku. 1999. "Aceh dalam Bingkai Negara Kesatuan Republik Indonesia”. Makalah Seminar Sastra Bandingan yang diselenggarakan di FakultasSastra UGM, Yogyakarta.

Juynboll, H.H. 1899. Catalogus van de Maleische en Sundaneesche Handschriften der Leidsche. Universiteits-Bibliotheek. E.J.Brill, Leiden.

Ricklefs, M.C. and P.Voorhoeve. 1977. Indonesian Manuscripts in Great Britain, A Catalogue of Manuscrips in Indonesian Languages in British PublicCollection. Oxford University Press, Oxford.

Ronkel, Ph.S. van. 1909. Catalogus der Maleische Handschriften in het Museumvan het Bataviaasch Genootchap van Kunsten en Wetenschappen. M. Nijhoff.VBG 57, 's-Hage.

Rujiati-Mulyadi, Sri Wulan. 1994. Kodikologi Melayu di Indonesia. Lembar Sastraedisi Khusus Fakultas Sastra Universitas Indonesia, Jakarta.

Sangidu, 1999. "Penyajian dan Interpretasi Teks Sastra Indonesia Klasik, KhususnyaNaskah-Naskah Jawi dan Naskah Berbahasa Arab". Majalah HUMANIORANomor 10 Januari-April, ISSN 0852-0801 Fakultas Sastra UGM, Yogyakarta.

Sutaarga, Moh. Amir, Jumsari Jusuf, Tuti Munawar, Ratnadi Greha, dan S.Z. Hadi Sutjipto. 1972. Koleksi Naskah Melayu Museum Pusat Dep. $P$ dan K. ProyekInventarisasi dan Dukumentasi Kebudayaan 
Jurnal CMES Volume X Nomor 2 Edisi Juli - Desember 2017

Program Studi Sastra Arab FIB UNS Surakarta

Nasional Direktorat Jenderal

Kebudayaan, Jakarta.

Voorhoeve, P., T.Iskandar, and M.Durie.

1994. Catalogue of Acehnese

Manuscriptsin The Library of

Leiden University and Other

Collections Outside Aceh.Leiden

University Library (Legatum

Warnerianum) [Seri ILDEP],

Leiden. 